* Graduado em Direito pela Universidade Federal do Ceará, Mestre em Ciência Política pelo Instituto Universitário de Pesquisas do Rio de Janeiro, Doutor em Direito pela Universidade de São Paulo e Livre-docente em Ciência Política pela Universidade Estadual do Ceará. Professor titular do Programa de Pós-Graduação em Direito Constitucional/Mestrado e Doutorado da Universidade de Fortaleza e parecerista. Experiência na área de Direito Constitucional e de Ciência Política, principalmente nos seguintes temas de pesquisa: constitucionalismo brasileiro; constituição política; teoria do Estado e da democracia; relações entre Legislativo e Executivo; reforma política.E-mail: filomeno@unifor.br

**Doutoranda em Direito Constitucional e Teoria Política na Universidade de Fortaleza (UNIFOR), mestre em Direito Constitucional (Direito e Desenvolvimento) pela Universidade Federal do Ceará (2002), especialização em Direito Processual pela ESMEC (Escola Superior da Magistratura do Estado do Ceará) e graduação em Direito pela Universidade de Fortaleza (UNIFOR). Experiência na área de Direito, com ênfase em Direito Constitucional, Introdução ao estudo do Direito, Direito Civil (parte geral e direito das coisas).Email: fabianacl.sa@gmail.com

\section{A Contribuição do Ministério Público para a Judicialização da Política e das Relações Sociais}

\author{
The Contribution of Public prosecutors to the \\ Judicialization of Politics and Social Relations
}

\section{José Filomeno de Moraes Filho* Fabiana Costa Lima de Sá**}

Como citar: MORAES FILHO, José Filomeno; SÁ, Fabiana Costa Lima de. A contribuição do Ministério Público para a judicialização da política e das relações sociais. Revista do Direito Público, Londrina, v. 15, n. 2, p. 116-134, ago. 2020. DOI: $10.5433 / 24157-108104-1.2020 v 15 n 2 p .116$. ISSN: $1980-$ $511 \mathrm{X}$.

Resumo: A discussão em torno da judicialização da política e das relações sociais tem ganhado espaço no campo jurídico brasileiro. Objetiva-se, nesta pesquisa, fazer uma reflexão sobre qual tem sido a colaboração do Ministério Público para o processo da judicialização da política e das relações sociais, tanto quando age como autor de ações do controle de constitucionalidade abstrato e ações civis públicas, como também quando atua como fiscal da lei. A metodologia da pesquisa é descritiva e qualitativa, foram utilizadas fontes bibliográficas, artigos científicos publicados em torno da matéria, documentos e, ainda, dados obtidos na internet. Inicialmente, analisa-se o papel atribuído ao Ministério Público pela Constituição Federal de 1988. Depois, busca-se entender qual a contribuição do Ministério Público para a judicialização da política e das relações sociais e, assim, conclui-se que o Ministério Público, enquanto autor de algumas ações, tem contribuído ativamente para o exercício desse processo, mas que sua atuação no controle de constitucionalidade abstrato foi bastante relevante em termos quantitativos, principalmente até 2016 e, em outras situações, quando atua como fiscal da lei, tem colaborado não para desencadear o processo, mas sim com o processo de judicialização da política já em exercício.

Palavras-chave: Ministério Público. Judicialização da política. Judicialização das relações sociais.

Abstract: In Brazil, discussions and debates surrounding the judicialization of politics and social relations has gained momentum in recent years. Therefore, this research examines the role of public prosecutors in the process of judicialization. Likewise, prosecutors can be both the petitioner of the control of 
abstract constitutionality of the Brazilian Federal Constitution and the author of public civil lawsuits. This paper uses descriptive and qualitative models, with bibliographical resources, such as scientific papers, documents and data obtained from the internet. Initially, this paper examines the role of the Public Prosecutor's Office from the perspective of the Brazilian Constitution. Afterwards, this paper investigates the Public Prosecutor's contribution to the judicialization of politics and social relations. Towards the end, this study concludes that the Public Prosecutor, as a petitioner, has actively contributed to the overuse of the judicialization process, but that its performance in the control of abstract constitutionality was quite relevant in quantitative terms mainly until 2016. In other situations, when acting as a prosecutor of the law, prosecutors have not collaborated in upholding the legal process, but rather act politically in the judicialization of facts.

Keywords: Public Prosecutor's Office. Judicialization of politics. Judicialization of social relations. 


\section{INTRODUÇÃO}

A judicialização da política e das relações sociais ganhou destaque no âmbito jurídico brasileiro. Com a expansão do direito na vida social houve uma explosão de litigiosidade e, consequentemente, uma maior procura pelo Poder Judiciário, que passou a ter papel relevante na resolução de conflitos políticos e sociais. E o Ministério Público ganhou novos contornos com o surgimento da Constituição de 1988, pois passou a ser visto como defensor da sociedade.

Propõe-se uma reflexão sobre a atuação do Ministério Público no processo de judicialização da política e das relações sociais, tanto quando age como autor de ações do controle de constitucionalidade abstrato e de ações civis públicas, mas também quando age como fiscal da lei. Pretende-se entender qual tem sido a contribuição do Ministério Público para esse processo, tendo a pesquisa relevância devido à possibilidade de ser auferida a responsabilidade do Ministério Público para o desencadeamento deste fenômeno.

O trabalho é fruto de pesquisa iniciada em 2016, quando se fez um apanhado dos dados fornecidos pelo Supremo Tribunal Federal sobre as ações do controle de constitucionalidade abstrato, considerando todas as ações que já tinham sido ingressadas desde 2000 até junho desse ano e as ingressadas antes de 2000, que ainda não tinham sido concluídas. No entanto, a pesquisa foi finalizada em 2017, quando foi feito novo apanhado dos dados estatísticos tornando possível perceber se, no período de um pouco mais de um ano, havia mudança ou não do perfil que, até então, tinha sido observado, momento esse em que o trabalho foi apresentado ao curso de doutorado do Programa de Pós Graduação em Direito da UNIFOR, como requisito parcial para a aprovação na disciplina democratização e controle do Poder Judiciário.

Primeiramente, é necessário contextualizar o papel atribuído ao Ministério Público pela Constituição Federal de 1988; para, em seguida, verificar qual a contribuição do Parquet, ao receber novos contornos pela atual Constituição Federal, no processo de judicialização da política e das relações sociais, para isso, passa-se a entender o fenômeno da judicialização da política e das relações sociais, expõem-se os dados estatísticos coletados e, ao final, analisa-se essa contribuição quando a instituição atua como autora de ações do controle abstrato e de ações civis públicas e também quando age como fiscal da lei.

A metodologia da pesquisa é descritiva e qualitativa, foram utilizadas fontes bibliográficas, artigos científicos publicados em torno da matéria, documentos e dados obtidos na internet. $\mathrm{O}$ estudo foi desenvolvido tendo por base a doutrina do Direito Constitucional e do Direito Processual Constitucional.

\section{O NOVO PERFIL DO MINISTÉRIO PÚBLICO}

O Ministério Público está disciplinado, na Constituição Federal de 1988, no capítulo IV, que trata das Funções Essenciais à Justiça, do Título IV - Da organização dos Poderes; enquanto os Poderes Legislativo, Executivo e Judiciário são cuidados pelos capítulos I, II e III do mesmo 
Título.

A atual Constituição tratou do Ministério Público em capítulo autônomo. Conceituou, estabeleceu garantias, conferiu autonomias à instituição, determinou vedações aos seus membros e traçou suas funções. O Ministério Público exerce, conforme o estabelecido no art. 127, função essencial à Justiça de forma permanente e com competência para a defesa da ordem jurídica, do regime democrático e dos interesses sociais e individuais indisponíveis.

O Ministério Público é uma instituição essencial ao exercício da função jurisdicional do Estado, porque a lei estabelece que a sua presença e sua atuação, em alguns casos, são imprescindíveis e, quando não observada a determinação legal, a jurisdição fica contaminada de nulidade absoluta.

É instituição permanente, porque é formada por um conjunto de órgãos que integram permanentemente o Estado. Tem a função de defender a ordem jurídica, pois cabe ao Ministério Público a defesa da Constituição Federal e da ordem infraconstitucional no caso de sua violação ou ameaça de violação.

Cabe ao Ministério Público também a defesa do regime democrático, ou seja, tem por missão defender a democracia, defender a soberania popular. E assume a posição de defensor dos interesses do povo, pois deve agir na proteção dos interesses sociais e dos interesses individuais indisponíveis, passando a ter um novo perfil enquanto defensor legítimo dos interesses da sociedade, e o fazendo de forma autônoma.

A instituição recebeu tratamento especial em capítulo próprio, estando, hoje, situado fora da estrutura dos Poderes Legislativo, Executivo e Judiciário e passando a ter autonomia e independência em relação a qualquer um destes Poderes Estatais.

Ao passar a exercer suas funções com autonomia, ${ }^{1}$ ganhou nova feição, pois, de acordo com a Constituição anterior, a outorgada em 1969, fazia parte da estrutura do Poder Executivo. Hoje, age sem sujeições a qualquer dos Poderes Estatais. Os seus membros apenas devem obediência à Constituição e ao ordenamento jurídico brasileiro, pois nem os superiores hierárquicos institucionais podem ditar regras para a atuação funcional dos membros do Ministério Público. A hierarquia existente é meramente administrativa e não funcional, cabendo a chefia administrativa ao Procurador-Geral.

Com autonomia funcional o Ministério Público não está sujeito aos Poderes Estatais e, assim, poderá ingressar com ações contra o Poder Legislativo, o Poder Executivo e contra o Poder Judiciário.

O Ministério Público abrange o da esfera da União, que está subdividido em: Ministério Público Federal; Ministério Público do Trabalho; Ministério Público Militar; Ministério Público do

\footnotetext{
1 Além de lhe ser garantida a autonomia funcional, a unidade e a indivisibilidade também lhes foram estabelecidas como princípios institucionais. A unidade significa que os seus membros pertencem a um só órgão, que é chefiado pelo Procurador -Geral, mas não há unidade entre o Ministério Público da União e dos Estados, nem entre os de Estados diferentes, nem entre os vários que compõem o Ministério Público da União. A unidade existe dentro de cada Ministério Público. A indivisibilidade significa que os membros do Ministério Público podem ser substituídos uns pelos outros da mesma instituição, pois a função exercida é do órgão.z
} 
Distrito Federal e Territórios. E ainda abrange o Ministério Público dos Estados. ${ }^{2}$ A Constituição Federal de 1988 concedeu ao Ministério Público as mesmas garantias dadas ao Poder Judiciário: vitaliciedade; inamovibilidade e irredutibilidade de vencimentos. ${ }^{3}$

As alterações, mais importantes, no perfil do Ministério Público, sugiram a partir da década de 1980. Adveio a Lei $n^{\circ}$ 6.938, de 31 de agosto de 1981, regulamentando a Política Nacional de Meio Ambiente, conferindo legitimidade ao Ministério Público para propor ação de responsabilidade civil e criminal em razão de danos ao meio ambiente (CARVALHO; LEITÃO, 2010). Mas, apenas com o surgimento do atual texto constitucional em 1988 é que a instituição passou a agir de forma independente e, ganhou autonomia funcional.

Assumiu o papel de defensor da sociedade, “[...] obteve a importante função de fiscalizar o cumprimento das leis e os próprios políticos [...]. Ou seja, foram garantidos ao Ministério Público papéis importantes dentro do cenário político nacional e tais papéis podem ser exercidos de maneira autônoma." (CARVALHO; LEITÃO, 2010, p. 400).

A lei que regulamentou a Política Nacional de Meio Ambiente foi bastante criticada pelos operadores do Direito, ainda que significasse um grande avanço, tanto por não abarcar outros interesses difusos, como também por ter dado legitimidade para a defesa do meio ambiente exclusivamente ao Ministério Público. Assim o Parquet seria o único com legitimidade ativa para propor ação de responsabilidade civil e criminal em face de danos causados ao meio ambiente (SILVA, 2001).

A primeira Lei Orgânica Nacional do Ministério Público ${ }^{4}$ adveio também em 1981 estabelecendo um estatuto uniforme para o Ministério Público. Surgiu a Lei 7.347, de 24 de julho de 1985, a Lei da Ação Civil Pública. Considerada um instrumento da maior importância para a sua atuação e com a garantia da autonomia funcional concedida pela Constituição Federal de 1988, a ação civil pública deixou de ser utilizada por uma instituição vinculada ao Poder Executivo, então, as ações do Ministério Público não são mais vistas como ações do próprio governo. Vale ainda ressaltar que "[...] esse instrumento foi ampliado de forma considerável para todos os interesses difusos e coletivos. Tudo isso garante um alto grau de autonomia ao Ministério Público brasileiro, sendo possível só após a Constituição de 1988." (CARVALHO; LEITÃO, 2010, p. 402).

A lei estabeleceu que a utilização da ação civil pública pode ocorrer por danos ao meio ambiente; danos ao consumidor; danos a bens e direitos de valor artístico, estético, histórico, turístico e paisagístico; que a legitimidade ativa, portanto legitimidade para propor a ação em defesa destes interesses difusos, foi dada ao Ministério Público, às associações, à administração descentralizada e a entes políticos: União, Estados e Municípios.

A Constituição Federal também lhe conferiu a independência administrativa, portanto, além da autonomia funcional, o Ministério Público goza também de autonomia administrativa. Ainda que não lhe seja concedida autonomia financeira, a instituição tem a competência para elaborar a proposta orçamentária dentro das limitações legais específicas e gerenciar os recursos

4 Lei complementar $n^{\circ} 40$, de 14 de dezembro de 1981. 
financeiros que lhe são destinados.

A criação de um ombudsman foi pensada quando os representantes do povo estavam reunidos em Assembleia Nacional Constituinte. O ombudsman é visto como uma instituição que, diante de abusos praticados pela Administração Pública, tem a finalidade de promover a defesa da cidadania. Mas, no Brasil, entendeu-se que o Ministério Público é a instituição competente para a proteção dos interesses da sociedade, não necessitando, desta forma, de outro órgão paralelo para defender o povo, pois o papel já foi assumido pelo Ministério Público. O Ministério Público, ao incorporar o papel do ombudsman, assumiu o controle dos Poderes Executivo, Legislativo e Judiciário.

\section{O MINISTÉRIO PÚBLICO DIANTE DA JUDICIALIZAÇÃO DA POLÍTICA E DAS RELAÇÕES SOCIAIS}

Propõe-se uma reflexão sobre a atuação do Ministério Público no processo de judicialização da política e das relações sociais. Assim, primeiramente, passa-se a entender o fenômeno da judicialização da política e das relações sociais, depois, expõem-se os dados estatísticos coletados no Supremo Tribunal Federal para, ao final, analisar a contribuição do Ministério Público quando atua como autor de ações do controle de constitucionalidade abstrato e de ações civis públicas, como também, quando age como fiscal da lei.

\subsection{Da Judicialização da Política e das Relações Sociais}

Para Luis Roberto Barroso (2012), a judicialização da política e das relações sociais, no Brasil, resultam, principalmente, dos seguintes fatores: adoção de uma Constituição analítica e abrangente e modelo de controle judicial de constitucionalidade vigente no país, em que adota tanto o sistema difuso como o sistema concentrado.

O controle difuso permite que qualquer juiz ou tribunal possa verificar a compatibilidade ou não da lei ou ato normativo infraconstitucional em relação à Constituição Federal, modelo que teve como fonte de inspiração o sistema americano. Já o concentrado é inspirado pelo sistema europeu, em que o controle é exercido diretamente pelo Supremo Tribunal Federal.

Ainda como causas para a judicialização apontam-se: a valorização, nas democracias modernas, do Poder Judiciário reconhecido como poder forte e independente; a crise de representatividade e legitimidade que afeta o Poder Legislativo; e a própria opção dos políticos em se manterem inertes, muitas vezes, em relação a certos assuntos que dividem a sociedade por serem polêmicos, deixando, assim, a tomada de decisão para o Poder Judiciário.

Com o fenômeno, "questões relevantes do ponto de vista político, social ou moral estão sendo decididas, em caráter final, pelo Poder Judiciário" (BARROSO, 2012, p. 366). Aponta-se que: 
[...] Nesse contexto, a judicialização constitui um fato inelutável, uma circunstância decorrente do desenho institucional vigente, e não uma opção política do Judiciário. Juízes e tribunais, uma vez que provocados pela via processual adequada, não têm a alternativa de se pronunciarem ou não sobre a questão. Todavia, o modo como venham a exercer essa competência é que vai determinar a existência ou não de ativismo judicial (BARROSO, 2012, p. 369).

Com o advento da Constituição Federal de 1988, a judicialização da política aparece, no Brasil, como um fato inevitável decorrente das mudanças que ocorreram nas instituições e não pode, portanto, ser caracterizada como uma opção tomada pelo Poder Judiciário, como uma postura a ser guiada pelo seu querer, por sua vontade. A judicialização da política decorre de alguns fatores e torna-se, assim, um fato que não se pode evitar. Para Clarissa Tassinari (2013, p. 32) a judicialização da política é:

[...] muito mais uma constatação sobre aquilo que vem ocorrendo na contemporaneidade por conta da maior consagração de direitos e regulamentações constitucionais, que acabam por possibilitar um maior número de demandas, que, em maior ou menor medida, desaguarão no Judiciário do que uma postura a ser identificada (como positiva ou negativa) [...]. Por tudo isso, pode-se dizer que a judicialização apresenta-se como uma questão social. A dimensão desse fenômeno, portanto, não depende do desejo ou vontade do órgão judicante. Ao contrário, ele é derivado de uma série de fatores originalmente alheios à jurisdição [...].

A judicialização é uma consequência de alguns fatores externos à jurisdição: a Constituição passou a reconhecer um maior número de direitos que, consequentemente, passou a gerar um maior número de conflitos e, assim, passou a haver uma maior busca pelo Poder Judiciário. O fenômeno não pode ser avaliado, portanto, como uma opção feita pelo julgador.

Quanto ao ativismo judicial, Tassinari (2013) entende contrariamente à judicialização, como um problema unicamente interno à jurisdição, como um problema estritamente jurídico, mas que reflete, obviamente, nas demais áreas. A existência do ativismo judicial não estaria justificada pela relação entre Direito e Política. A judicialização surge quando as manifestações dos demais poderes são insuficientes, e o ativismo é uma opção tomada pelo Poder Judiciário em comportarse extrapolando os limites estabelecidos constitucionalmente. Então, o ativismo judicial é visto apenas em um aspecto negativo, pois decisão ativista seria a proferida exorbitando os limites constitucionais.

Para Marco Felix Villalobos (2016), o elemento crucial da judicialização da política é o deslocamento para o Poder Judiciário de alguns temas, com o propósito de que esses assuntos sejam avaliados pelos juízes. A judicialização da política consiste, em síntese, em conceder aos Tribunais o controle sobre outros órgãos públicos ou utilizá-los como arena para a resolução de questões que antes eram solucionadas no âmbito do Poder Legislativo ou do Poder Executivo.

No mesmo sentido, Rodrigo Upimny Yepes (2007) entende que a judicialização da política decorre do fato de que certos assuntos que antes eram, por tradição, decididos por meios políticos 
e considerados típicos da política democrática, passaram a ser decididos cada vez mais no âmbito judicial ou estão fortemente condicionados por decisões judiciais

A judicialização da política é fruto da adoção, pela Constituição Federal de 1988, do controle abstrato de constitucionalidade das leis. "A política se judicializa a fim de viabilizar o encontro da comunidade com os seus propósitos, declarados formalmente na Constituição [...] longe de enfraquecer o sistema dos partidos [...] tende a reforçá-los [...]”, possibilita a sociedade legitimamente a "[...] deflagrar o processo judicial contra as instâncias do poder [...]", possibilita a comunidade de intérpretes da Constituição a provocar o controle abstrato de constitucionalidade perante o Supremo Tribunal Federal (VIANNA et al., 1999, p. 47).

O direito na contemporaneidade vem abarcando "[...] a regulação da sociabilidade e das práticas sociais [...]", abrangendo, inclusive, práticas sociais que, por tradição, eram vistas como puramente privadas. A judicialização das relações sociais diz respeito à expansão da capacidade do direito de normatizar as relações sociais, abarcando, inclusive, práticas sociais tradicionalmente privadas. Consiste na "[...] crescente invasão do direito na organização da vida social [...]". O Judiciário passa, então, a expandir a sua atuação diante da percebida "[...] incapacidade de o Executivo e o Legislativo fornecerem respostas efetivas à explosão das demandas sociais por justiça [...].” (VIANNA et al., 1999, p. 149).

Conclui-se que a judicialização da política e das relações sociais é uma consequência das modificações estruturais ocorridas. Com o advento do Estado Democrático de Direito e a promulgação da Constituição Federal de 1988, o fenômeno tornou-se um fato que não se pode evitar, principalmente, em razão dos modelos de Constituição e de controle de constitucionalidade adotados. E que surge em razão da omissão dos demais poderes, mas não diz respeito a uma escolha feita pelos magistrados.

A judicialização da política consiste na capacidade assumida pelo Poder Judiciário em garantir os direitos fundamentais dos cidadãos. Antoine Garapon (2001, p. 44) afirma que em vários países "[...] se vê o poder político transferir algumas de suas tarefas para o juiz [...]" e ainda alerta que a "[...] justiça não pode se colocar no lugar da política; do contrário arrisca-se a abrir caminho para uma tirania das minorias [...]..

No exercício da judicialização da política e das relações sociais o Poder Judiciário passa a ser relevante na resolução de conflitos políticos e sociais, pois passa a ter um papel central na efetivação de direitos e implementação de políticas públicas. E qual será a contribuição do Ministério Público para o exercício da judicialização da política e das relações sociais? Como o Ministério Público vem contribuindo concretamente para o desencadeamento destes fenômenos?

Para se chegar a uma resposta ao que se propõe, primeiramente, expõem-se os dados estatísticos levantados sobre o quantitativo de ações do controle abstrato de constitucionalidade, que já foram propostas perante o Supremo Tribunal Federal até julho de 2017. Considera-se, também, dentre os vários legitimados para propor as ações, quem mais exerceu essa iniciativa e, para isso, apresenta-se o quantitativo e o percentual da participação daqueles que aparecem nos cinco primeiros lugares. 


\subsection{Dados Estatísticos Sobre as Ações do Controle Abstrato de Constitucionalidade, Atualizados até Julho de 2017}

Verificando os dados estatísticos disponíveis no site do STF, aponta-se que foram ingressadas, até dia 12 de junho de $2016,{ }^{5} 5.042$ ações diretas de inconstitucionalidade. Em termos quantitativos, o Procurador-Geral da República ingressou com 941, representando 18,66\% do total; em segundo lugar, vem o Conselho Federal da OAB, com 152, representando 3,01\%; em terceiro lugar, o Partido Democrático Trabalhista-PDT, com 135, representando 2,68\%; em quarto lugar, o Governador do Estado de São Paulo, com 131, representando 2,60\% e em quinto lugar, a Associação dos Magistrados Brasileiros, com 129, representando 2, 56\%; dentre outros (BRASIL, 2016). Ainda considerando que outros partidos políticos, governadores de Estados ou do Distrito Federal e outras entidades de classe também ingressaram com outras ações e que no somatório podem ultrapassar o número de ações ingressadas pelo Procurador-Geral da República, verifica-se que o Procurador-Geral da República, isoladamente considerado, foi o que mais ingressou com ações diretas de inconstitucionalidade.

Apenas 38 ações diretas de inconstitucionalidade por omissão chegaram ao STF até 12 de junho de 2016. ${ }^{6}$ O Procurador-Geral da República ingressou com 3, representando 7,89\%; a Associação dos Delegados de Polícia do Brasil com 2, representando 5,26\%; a Associação Nacional dos Agentes de Segurança do Poder Judiciário também com 2, também representando 5,26\%; o Conselho Federal da Ordem dos Advogados do Brasil com 2, também representando 5,26\%, e o Partido Solidariedade também com 2; representando 5,26\%; dentre outros (BRASIL, 2016). Portanto, mesmo considerando que outras entidades de classe e outros partidos políticos ingressaram com outras ações e que no somatório ultrapassam o número de ações ingressadas pelo Procurador-Geral da República, mas percebendo que enquanto são muitos os partidos políticos, muitas as entidades de classe e ainda muitos os governadores, o Procurador-Geral da República, isoladamente considerado, foi quem mais entrou com as ações.

Foram 46 ações declaratórias de constitucionalidade até 12 de junho de $2016 .^{7}$ Entre os legitimados, em primeiro lugar vem o Presidente da República, com 6, representando 13, 04\%; em segundo lugar, o Procurador-Geral da República, com 4, representando 8,70\%; o Conselho Federal da Ordem dos Advogados do Brasil, com 3, representando 6,52\%; a Mesa do Senado também com 3, também representando 6,52\%, e o governador do Distrito Federal com 2, representado 4,35\%; dentre outros (BRASIL, 2016). Mais governadores ingressaram com ações, totalizando 3, representando no total 6,52\%; o número total de ações ingressadas por vários partidos políticos e por várias entidades de classe ultrapassa o número de ações que foram propostas pelo Presidente

5 O site do STF informa que os dados estatísticos são referentes aos processos em trâmite a partir de 2000 e aos autuados anteriormente, mas que ainda não foram concluídos.

6 O site do STF informa que os dados estatísticos são referentes aos processos em trâmite a partir de 2000 e aos autuados anteriormente, mas que ainda não foram concluídos.

7 O site do STF informa que os dados estatísticos são referentes aos processos em trâmite a partir de 2000 e aos autuados anteriormente, mas que ainda não foram concluídos. 
da República, mas, este, de forma isolada, foi quem mais ingressou com essas ações.

São 418 ADPF's até dia 12 de junho de $2016^{8}$ no STF. O Procurador-Geral da República entrou com 33, representando 7,89\%; o Partido Socialismo e Liberdade -PSOL com 13, representando 3,11\%; Democratas, 12, representando 2,87\%; o Partido Democrático Trabalhista -PDT com 10, representando 2,39\%, e o Partido da Social Democracia Brasileira - PSDB com 9 , representando 2,15\%, dentre outros (BRASIL, 2016). Mesmo verificando que o número total de ações propostas pelos vários partidos ultrapassa o de ações propostas pelo Procurador-Geral da República, verifica-se, que individualmente considerado, o Procurador-Geral da República foi quem mais entrou com essas ações.

Em 2017, ocorreram algumas alterações nos dados estatísticos. Percebe-se que 14.873 ações diretas de inconstitucionalidade foram ingressadas até 02 de julho de $2017 .{ }^{9}$ Em termos quantitativos, o Presidente da República ingressou com 1.117, representando 7,91\% do total; em segundo lugar, vem o Procurador-Geral da República com 1004, representando 6,75\% do total; em terceiro lugar, o Congresso Nacional, com 888, representando 5,97\%; em quarto lugar, a Assembleia Legislativa do Estado do Rio de Janeiro, com 264, representando 1,78\% e em quinto lugar, o Governador do Estado de São Paulo, com 222, representando 1,49\%; dentre outros (BRASIL, 2017). Comparando o número total de ações ingressadas até 12 de junho de 2016 e o total até 02 de julho de 2017, verifica-se que foram propostas, somente neste período de um ano e poucos dias, o total de 9.831 e que o Presidente da República, que antes não figurava entre os cinco primeiros lugares, agora encontra-se como o que mais ingressou com essas ações, portanto, mais contribuiu para o processo de judicialização da política, ficando o Procurador Geral da República em segundo lugar. O Procurador-Geral da República ingressou, neste período, com apenas com 63, e o Congresso Nacional, que também não estava entre os cinco primeiros, passou a se posicionar em terceiro lugar.

Até 02 de julho de 2017, 195 ações diretas de inconstitucionalidade por omissão chegaram ao STF. ${ }^{10}$ O Congresso Nacional ingressou com 18, representando 9,23\%; o Presidente da República com 14, representando 7,18\%; o Procurador-Geral da República com 5, representando 2,56\%; o Estado de Goiás com 3, representando 1,54\%, e o Governador do Estado de Minas também com 3; também representando 1,54\%; dentre outros (BRASIL, 2017). Portanto, comparando o número total de ações ingressadas até 12 de junho de 2016 e até 02 de julho de 2017, verifica-se que, neste período de um ano e poucos dias, foram propostas 157 ações de inconstitucionalidade por omissão. O Congresso Nacional e o Presidente da República, que antes não figuravam entre os cinco primeiros lugares, agora, são os que mais ingressaram com essas ações, ficando em primeiro lugar o Congresso Nacional, e o Presidente da República, em segundo, passando o ProcuradorGeral da República para o terceiro lugar, que ingressou apenas com mais duas.

8 O site do STF informa que os dados estatísticos são referentes aos processos em trâmite a partir de 2000 e aos autuados anteriormente, mas que ainda não foram concluídos.

9 O site do STF informa que os dados estatísticos são referentes aos processos em trâmite a partir de 2000 e aos autuados anteriormente, mas que ainda não foram concluídos.

$10 \mathrm{O}$ site do STF informa que os dados estatísticos são referentes aos processos em trâmite a partir de 2000 e aos autuados anteriormente, mas que ainda não foram concluídos. 
Foram 162 ações declaratórias de constitucionalidade até 02 de julho de $2017 .{ }^{11}$ Entre os legitimados, em primeiro lugar vem o Presidente da República, com 24, representando 14, 81\%; em segundo lugar o Congresso Nacional, com 16, representando 9,88\%; o Conselho Federal da Ordem dos Advogados do Brasil, com 4, representando 2,47\%; o Procurador-Geral da República, também com 4, também representando 2,47\%, e o governador do Distrito Federal, com 3, representado 1,85\%; dentre outros (BRASIL, 2017). O número total de ações ingressadas por vários partidos políticos e por várias entidades de classe ultrapassam o número de ações propostas pelo Presidente da República, mas este, de forma isolada, foi ainda quem mais ingressou com essas ações, como já era até 12 de junho de 2016. Percebe-se que o Congresso Nacional passou a aparecer entre os cinco primeiros, posicionando-se em segundo lugar.

São 1.596 ADPF's até dia 02 de julho de 2017 no STF. ${ }^{12}$ O Presidente da República entrou com 111, representando 6,95\%; o Congresso Nacional com 50, representando 3,13\%; o Procurador-Geral da República, com 40, representando 2,51\%; o Tribunal Superior Eleitoral, com 21, representando 1, 32\%, e a União, com 18, representando 1,13\%, dentre outros (BRASIL, 2017). Mais uma vez, verifica-se que o Procurador-Geral da República deixou de ser quem isoladamente considerado mais entrou com ações e que o Presidente da República e o Congresso Nacional, que antes não estavam entre os cinco primeiros lugares, agora, ocupam, respectivamente, o primeiro e segundo lugar, ficando o Procurador-Geral da República em terceiro.

Resta, agora, considerando os dados obtidos no site do Supremo Tribunal Federal, concluir sobre a contribuição do Ministério Público na judicialização da política e das relações sociais enquanto autor das ações no controle de constitucionalidade abstrato até a data em que a pesquisa foi finalizada, julho de 2017. Mas, também analisar a sua atuação como autor das ações civis públicas e como fiscal da lei.

\subsection{A Contribuição do Ministério Público Para o Processo da Judicialização da Política e das Relações Sociais, Enquanto Autor das Ações do Controle Abstrato de Constitucionalidade e das Ações Civis Públicas, e, ainda, como Fiscal da Lei}

Lembrando que o regramento constitucional concedeu ao Ministério Público função essencial à Justiça de forma permanente e com competência para a defesa da ordem jurídica, do regime democrático e dos interesses sociais e individuais indisponíveis. E que com o texto constitucional de 1988 a instituição passa a ter autonomia e independência em relação a qualquer um dos Poderes Estatais.

Cabe examinar qual a atividade exercida pelo Ministério Público que impulsiona a judicialização da política e das relações sociais, considerando os fatores determinantes destes fenômenos e o novo perfil assumido pelo Ministério Público, como instituição permanente e

$11 \mathrm{O}$ site do STF informa que os dados estatísticos são referentes aos processos em trâmite a partir de 2000 e aos autuados anteriormente, mas que ainda não foram concluídos.

$12 \mathrm{O}$ site do STF informa que os dados estatísticos são referentes aos processos em trâmite a partir de 2000 e aos autuados anteriormente, mas que ainda não foram concluídos. 
independente e como defensor da ordem democrática, do regime democrático e dos interesses sociais e individuais indisponíveis.

Como fator explicativo da judicialização da política e das relações sociais foi apontado que este fenômeno é fruto da adoção de uma Constituição analítica e abrangente e do modelo de controle judicial de constitucionalidade vigente no país. E ainda lembrando que foi ressaltada como fator determinante a adoção, no Brasil, do controle abstrato de constitucionalidade. Assim, entendese essencial analisar o papel do Ministério Público neste controle judicial de constitucionalidade dos atos normativos, já que é visto como fator determinante da judicialização da política.

$\mathrm{O}$ controle de constitucionalidade pode ser classificado quanto ao objeto visado em concreto e abstrato. No controle concreto (incidental ou por via de exceção ou defesa), o objetivo principal no processo não é a declaração de inconstitucionalidade em tese do ato normativo, mas sim a realização de um interesse concreto, particular, e a produção de efeitos da decisão se faz apenas entre as partes em conflito. No controle abstrato (principal ou por via de ação), o objetivo principal é a declaração de inconstitucionalidade em tese do ato normativo, e não a proteção interesses concretos, particulares. Já os efeitos da decisão são oponíveis contra todos.

Mas, em razão do fim almejado no presente trabalho, entende-se necessária a delimitação do objeto a ser pesquisado e analisado. Concentrar-se-á no entendimento tão somente de um destes controles de constitucionalidade, qual seja, o controle abstrato, até porque considerado como fator determinante da judicialização da política por Luis Werneck Vianna et al. (1999).

O controle de constitucionalidade de atos normativos produz efeitos políticos, e a judicialização da política é analisada no âmbito da revisão judicial dos atos do Executivo e dos atos do Legislativo. As ações de inconstitucionalidade "[...] têm sido consideradas um dos instrumentos que mais caracteriza a judicialização da política, pois as decisões afetam diretamente as normas estipuladas pelo Legislativo." (ARAGÃO, 2013, p. 70).

Passa-se a analisar a participação do Ministério Público nas seguintes ações constitucionais: ação direta de inconstitucionalidade; ação direta de inconstitucionalidade por omissão; ação declaratória de constitucionalidade e arguição de descumprimento de preceito fundamental. $\mathrm{O}$ art. $103^{13}$ da Constituição Federal de 1988 estabeleceu a legitimidade ativa para propor a ação direta de inconstitucionalidade por ação ou omissão ${ }^{14}$ e a ação declaratória de constitucionalidade, ${ }^{15}$ dentre os quais está o Procurador-Geral da República.

Os outros legitimados para propor a ação direta de inconstitucionalidade por ação ou omissão e a ação declaratória de constitucionalidade são: o Presidente da República; as mesas do Senado Federal, da Câmara dos Deputados ${ }^{16}$ e das Assembleias Legislativas dos Estados ou da Câmara Legislativa do Distrito Federal; ${ }^{17}$ o Governador de Estado ou do Distrito Federal; ${ }^{18}$

13 Redação dada pela Emenda n. 45, de 30 de dezembro de 2004.

14 Determinação do art. 12 -A da Lei 9.868, de 10 de novembro de 1999, artigo que foi acrescentado pela Lei 12.063, de 27 de outubro de 2009.

15 Foi acrescentada pela Emenda Constitucional n. 3, de 17 de março de1993.

16 Apenas mesa do Senado e mesa da Câmara dos Deputados, não está inclusa a mesa do Congresso Nacional.

17 Alterado pela Emenda Constitucional n. 45/2004.

18 Também alterado pela Emenda Constitucional n. 45/2004. 
o Conselho Federal da Ordem dos Advogados do Brasil; partido político com representação no Congresso Nacional e a confederação sindical ou entidade de classe de âmbito nacional.

Alguns dos legitimados precisam demonstrar a pertinência temática, mas o ProcuradorGeral da República é legitimado universal, portanto, não precisa demonstrar a pertinência temática, não precisa demonstrar interesse relacionado à sua finalidade institucional.

Vale ressaltar que mesmo a ação direta de inconstitucionalidade sendo proposta pelo Procurador Geral da República, posteriormente, decorrido o prazo das informações, o Advogado Geral da União e ele, o Procurador-Geral da República, deverão manifestar-se, cada um, no prazo de 15 dias, ${ }^{19}$ podendo este último, inclusive, manifestar-se pela sua improcedência.

O Procurador-Geral da República é o único dos legitimados ativos que também funciona nas respectivas ações com outras atribuições, pois também atua como custos legis. A atuação obrigatória na ação declaratória de constitucionalidade como custos legis foi disciplinada pelo art. 19 da Lei 9.868/99.

E a sua atuação na ação direta de inconstitucionalidade por omissão foi cuidada pelo art. 12-E, $\S 3^{\circ}$ da Lei 9.868/99, dispondo que o Procurador-Geral da República, decorrido o prazo para informações, terá vistas do processo nas ações em que não for autor, no prazo de quinze dias.

A Lei 9.882, de 3 de dezembro de 1999, que regulamentou a arguição de descumprimento de preceito fundamental, estabeleceu em seu art. $2^{\circ}$ que os legitimados para propor a ação direta de inconstitucionalidade também são legitimados para propor a arguição de descumprimento de preceito fundamental.

Portanto, dentre outros, o Procurador Geral da República também poderá propor a arguição de descumprimento de preceito fundamental e é considerado como legitimado universal, ele poderá propor a ação em qualquer circunstância. Após ter decorrido o prazo para informações, o Ministério Público terá vistas do processo, por cinco dias, nas arguições em que não formulou o pedido. ${ }^{20}$

A participação do Ministério Público no desencadeamento do exercício da judicialização da política ocorre pela sua possibilidade de agir como autor nessas ações de inconstitucionalidade. Como é legitimado ativo, dentre outros, termina por impulsionar o exercício da judicialização da política, chamando o Poder Judiciário a tomar decisões com efeitos políticos e contribuindo efetivamente para que seja exercida.

Mas, a sua atuação como autor não é fator determinante ou, explicativo para a existência do fenômeno em termos teóricos, uma vez que já apontado que o que determinou a existência da judicialização da política e das relações sociais foi a adoção tanto do modelo de constituição analítica, como do modelo de controle judicial de constitucionalidade. Vale lembrar mais uma vez que a adoção do controle abstrato é que responde pela existência da judicialização da política. Portanto, pode-se afirmar que o Ministério Público não responde teoricamente pela existência da judicialização da política, mas que contribui de forma decisiva para o seu exercício, pois

19 Determinação do art. $8^{\circ}$ da Lei 9.868 (lei que dispõe sobre o processo e julgamento da ação direta de inconstitucionalidade e da ação declaratória de constitucionalidade perante o Supremo Tribunal Federal).

20 Ver art. $7^{\circ}$, parágrafo único, da Lei 9.882/99. 
impulsiona a sua viabilidade prática, tornando possível a sua efetividade, assim como qualquer outro dos legitimados ativos no controle judicial abstrato.

E quando o Ministério Público atua como custos legis é certo que não está a impulsionar o exercício da judicialização da política, não está contribuindo para que ela seja exercida. Está a contribuir com o processo de judicialização já desencadeado, em exercício. Assim, a sua contribuição não é para o processo de judicialização da política, e sim com o processo da judicialização da política.

E observando os dados estatísticos apresentados, anteriormente, conclui-se que o Procurador-Geral da República muito contribuiu, de 2000 até 12 de junho de 2016, enquanto autor das ações proposta perante o Supremo Tribunal Federal no controle abstrato de constitucionalidade, para o exercício da judicialização da política. Ele foi, até a data mencionada, o que mais ingressou com as ações diretas de inconstitucionalidade, com as ações de inconstitucionalidade por omissão e com as ADPF's, desde que seja considerado que são muitos os partidos políticos, muitos os governadores e muitas as entidades de classe e que quando somadas as ações propostas por estes o seu número total pode ser maior que o número total de ações propostas pelo Procurador-Geral da República, mas uma vez percebendo que o Procurador-Geral da República é um só, verifica-se que teve um papel mais ativo que os outros considerados em suas individualidades.

No entanto, percebe-se que, em um lapso temporal de um pouco mais de 1 ano, ocorreu uma mudança significativa, deixando de ser o Procurador-Geral da República o que mais contribuiu para o exercício da judicialização da política; pois o Presidente da República, isoladamente considerado, passou a ser o que mais ingressou até 02 de julho de 2017 com as ações diretas de inconstitucionalidade, com as ações declaratórias de constitucionalidade e com as ADPF's.

Lembrando que, além do modelo de controle judicial de constitucionalidade adotado, foi apontado como fator explicativo da judicialização da política e das relações sociais o modelo de constituição, a adoção de uma Constituição analítica.

Quanto à extensão, as Constituições são classificadas em sintéticas e analíticas. As analíticas são também chamadas de extensas e tratam de assuntos “[...] formalmente constitucionais (v.g., meio ambiente, uniões estáveis, direito de filiação etc.), além de normas programáticas [...]"; já as sintéticas, também chamadas de reduzidas, cuidam de assuntos "[...] materialmente constitucionais (separação dos poderes e direitos fundamentais) [...]" (CAMBI, 2016, p. 73 e 74).

Com a expansão do direito na vida social, houve uma expansão de litigiosidade e, consequentemente, uma maior busca pelo Poder Judiciário para que solucione conflitos coletivos de natureza política e social. A Constituição passou a abranger um maior número de direitos, ocasionando um maior número de conflitos e, assim, passou a haver uma maior procura pelo Poder Judiciário.

Resta examinar a atividade desenvolvida pelo Ministério Público em defesa da efetivação dos direitos constitucionalmente assegurados, o papel do Ministério Público enquanto defensor da sociedade. Já que se pretende associar a atuação do Ministério Público ao fenômeno da judicialização, limitar-se-á a verificar a sua atuação no âmbito judicial, desconsiderando, portanto, 
a sua atuação extrajudicial.

A ação civil pública é um instrumento processual importante na defesa de direitos metaindividuais. Apesar de existirem outras formas processuais na defesa desses direitos, não são objeto de estudo nesse trabalho. A ação civil pública pode ser ingressada para a proteção ao meio ambiente; ao consumidor; a bens e direitos de valor artístico, estético, histórico, turístico e paisagístico; a qualquer outro interesse difuso ou coletivo; por infração da ordem econômica e da economia popular; e à ordem urbanística, à honra e à dignidade de grupos raciais, étnicos ou religiosos, ao patrimônio público e social para a reparação de danos morais e patrimoniais ${ }^{21}$.

Com legitimidade para ingressar com a ação civil pública o Ministério Público assume, desta maneira, papel fundamental na defesa de interesses difusos e coletivos. Para Arantes (1999, p. 83):

O Ministério Público tem sido o agente mais importante da defesa de direitos coletivos pela via judicial e, dado que os conflitos relativos a tais direitos têm geralmente conotação política, pode-se dizer que também tem impulsionado um processo mais amplo de judicialização de conflitos políticos e, no sentido inverso, de politização do sistema judicial.

Para o autor, o Ministério Público tem desenvolvido um papel relevante na defesa dos direitos coletivos no âmbito judicial e tem, assim, impulsionado o processo de judicialização da política. Arantes (1999, p. 89) ainda aponta que “[...] hoje o MP é o responsável pela maior parte das ações civis públicas em tramitação na Justiça [...]”. Deve ser ressaltado, porém, que o próprio autor sinaliza em nota de rodapé que não há dados estatísticos que comprovem com precisão o afirmado.

No mesmo sentido, Mona Lisa Ismail (2014, p. 190): “[...] apesar de haver uma série de colegitimados a sua propositura, o Ministério Público é o litigante com o maior número de ações civis públicas ajuizadas [...]." Portanto, diante do que foi apresentado por Arantes e Mona Lisa Ismail, percebe-se que o Ministério Público tem colaborado ativamente para o desencadeamento da judicialização das relações sociais.

A Lei 7.347/85 estabeleceu em seu art. $5^{\circ}$ os legitimados para propor a ação civil pública e determinou que são também legitimados: a Defensoria Pública, a União, os Estados, o Distrito Federal, os Municípios, as autarquias, as empresas públicas, as fundações e sociedades de economia mista, além das associações que preencherem os requisitos legais. A legitimidade do Ministério Público para propor a ação civil pública também está prevista no art. 129, III, da Constituição Federal de 1988.

Pode ainda o Ministério Público atuar no processo como custos legis, segundo o art. $5^{\circ}, \S 1^{\circ}$ da Lei 7.347/85. Caso não seja parte no processo, a sua participação como fiscal da lei, é obrigatória. Pode, então, como fiscal da lei colaborar com o processo de judicialização da política e das relações sociais já desencadeado, e não para o desencadeamento do processo de judicialização 
da política e das relações sociais. Portanto, quando o Ministério Público atua como fiscal da lei, é certo que não está a impulsionar o exercício da judicialização da política e das relações sociais, não está contribuindo para desencadear a judicialização da política e das relações sociais. Está a contribuir com o processo de judicialização já desencadeado, em exercício.

\section{CONCLUSÃO}

O Ministério Público é instituição permanente e exerce, conforme o estabelecido no art. 127, função essencial à Justiça, com competência para a defesa da ordem jurídica, do regime democrático e dos interesses sociais e individuais indisponíveis. Recebeu tratamento especial em capítulo autônomo, estando, hoje, situado fora da estrutura dos Poderes Legislativo, Executivo e Judiciário e passando a ter autonomia e independência em relação a qualquer um destes Poderes Estatais. Assumiu o papel de defensor da sociedade.

A judicialização da política e das relações sociais é uma consequência das modificações estruturais ocorridas. Com o advento do Estado Democrático de Direito e a promulgação da Constituição Federal de 1988, o fenômeno tornou-se um fato. A judicialização da política e das relações sociais decorre dos modelos de Constituição e de controle de constitucionalidade adotados e surge em razão da omissão dos demais poderes.

Conclui-se que o Ministério Público contribui para o desencadeamento do exercício da judicialização da política quando age como autor nas ações de inconstitucionalidade. Como é legitimado ativo, dentre outros, termina por impulsionar o exercício da judicialização da política. Chamando o Poder Judiciário a tomar decisões com efeitos políticos, contribui efetivamente para que seja exercida. Mas, não responde teoricamente pela existência da judicialização da política e das relações sociais, apesar de impulsionar sua viabilidade prática.

O Procurador-Geral da República, de 2000 até 12 de junho de 2016, foi quem mais ingressou com as ações diretas de inconstitucionalidade, com as ações de inconstitucionalidade por omissão e com as ADPF's, portanto, muito contribuiu, enquanto autor das ações no controle abstrato de constitucionalidade, para o exercício da judicialização da política, tendo um papel mais ativo que os outros considerados em suas individualidades até a data mencionada.

Mas, em um ano e poucos dias, ocorreu uma mudança significativa, pois o Presidente da República é quem passou a ter um papel mais ativo. Até 02 de julho de 2017 passa a figurar como o que mais ingressou com as ações diretas de inconstitucionalidade, com as ações declaratórias de constitucionalidade e com as ADPF's.

Considerando que o Ministério Público tem sido, dentre os legitimados para propor ação civil pública em defesa de direito difusos e coletivos, o mais atuante, conclui-se que tem colaborado ativamente para o desencadeamento da judicialização das relações sociais.

E quando o Ministério Público atua como fiscal da lei, é certo que não está a impulsionar o exercício da judicialização da política e das relações sociais, não está contribuindo para a judicialização da política e das relações sociais. Está tão somente a atuar em um processo de 
judicialização já desencadeado, em exercício. Assim, a sua contribuição não é para o processo de judicialização da política e das relações sociais, e sim com o processo da judicialização da política e das relações sociais.

\section{REFERÊNCIAS}

ARAGÃO, João Carlos Medeiros de. Judicialização da política no Brasil: influência sobre atos interna corporis do Congresso Nacional. Brasília: Câmara dos Deputados, 2013.

ARANTES, Rogério Bastos. Direito e política: o Ministério Público e a defesa dos direitos coletivos. Revista Brasileira de Ciências Sociais, São Paulo, v. 14, n. 39, p. 83-102, fev.1999.

BARROSO, Luís Roberto. Judicialização, ativismo e legitimidade democrática. [Syn] Thesis, São Paulo, v. 5, n. 1, p. 23 -32, 2012.

BRASIL. Emenda constitucional no 1, de 17 de outubro de 1969. Edita o novo texto da Constituição Federal de 24 de janeiro de 1967. Diário Oficial: Seção 1, Brasília, DF, parte 1, 20 out. 1969. Disponível em: http://www.planalto.gov.br/ccivil_03/constituicao/emendas/ emc anterior1988/emc01-69.htm. Acesso em: 5 jul. 2019.

BRASIL. [Constituição (1988)]. Constituição da República Federativa do Brasil de 1988. Brasília: Presidência da República, 1988. Disponível em: http://www.planalto.gov.br/ccivil_03/ Constituicao/Constituicao.htm. Acesso em: 28 nov. 2017.

BRASIL. Emenda Constitucional no 3, de 17 de março de 1993. Altera os arts. 40, 42, 102, 103, 155, 156, 160, 167 da Constituição Federal. Brasília, DF: Presidência da República, 1993. Disponível em: http://www.planalto.gov.br/ccivil_03/Constituicao/Emendas/Emc/ emc03. htm\#art1. Acesso em: 28 nov. 2017.

BRASIL. Emenda Constitucional $\mathbf{n}^{\mathbf{0}} \mathbf{4 5}$, de 08 de dezembro de 2004. Altera dispositivos dos arts. $5^{\circ}, 36,52,92,93,95,98,99,102,103,104,105,107,109,111,112,114,115,125,126$, 127, 128, 129, 134 e 168 da Constituição Federal, e acrescenta os arts. 103-A, 103B, 111-A e 130-A, e dá outras providências. Brasília: Presidência da República, 2004. Disponível em: http:// www.planalto.gov.br/ccivil_03/Constituicao/Emendas/Emc/ emc45.htm\#art9. Acesso em: 28 nov. 2017.

BRASIL. Lei complementar 40, de 14 de dezembro de 1981. Estabelece normas gerais a serem adotadas na organização do Ministerio Público Estadual. Brasilia, DF: Presidência da República, 1981a. Disponível em: http://www.planalto.gov.br/ccivil_03/leis/lcp/lcp40.htm. Acesso em: 23 jul. 2017.

BRASIL. Lei n ${ }^{\circ} 6.938$, de 31 de agosto de 1981. Dispõe sobre a Política Nacional do Meio Ambiente, seus fins e mecanismos de formulação e aplicação, e dá outras providências. Diário Oficial da União: Seção 1, Brasília, DF, 2 set. 1981b, p. 16509. Disponível em: http://www2. camara.leg.br/legin/fed/lei/1980-1987/lei-6938-31-agosto-1981-366135-normaatualizada-pl.pdf. Acesso em: 23 jul. 2017.

BRASIL. Lei 7.347, de 24 de julho de 1985. Disciplina a ação civil pública de responsabilidade por danos causados ao meio-ambiente, ao consumidor, a bens e direitos de valor artístico, 
estético, histórico, turístico e paisagístico (VETADO) e dá outras providências. Brasília: Presidência da República, 1985. Disponível em: http://www.planalto.gov.br/ccivil_03/leis/ L7347orig.htm. Acesso em: 16 jun. 2016.

BRASIL. Lei 9.868, de 10 de novembro de 1999. Dispõe sobre o processo e julgamento da ação direta de inconstitucionalidade e da ação declaratória de constitucionalidade perante o Supremo Tribunal Federal. Brasília, DF: Presidência da República, 1999a. Disponível em: http://www. planalto.gov.br/ccivil_03/leis/L9868.htm. Acesso em: 14 jun. 2016.

BRASIL. Lei 9.982, de 3 de dezembro de 1999. Dispõe sobre o processo e julgamento da argüição de descumprimento de preceito fundamental, nos termos do $\S 1$ o do art. 102 da Constituição Federal. Brasília, DF: Presidência da República, 1999b. Disponível em: http://www. planalto.gov.br/ccivil_03/leis/19882.htm. Acesso em: 14 jun. 2016.

BRASIL. Lei 12.063, de 27 de outubro de 2009. Acrescenta à Lei no 9.868, de 10 de novembro de 1999, o Capítulo II-A, que estabelece a disciplina processual da ação direta de inconstitucionalidade por omissão. Brasília, DF: Presidência da República, 2009. Disponível em: http://www.planalto.gov.br/ccivil_03/_ato2007-2010/2009/lei/112063.htm. Acesso em: 14 jul. 2017.

BRASIL. Supremo Tribunal Federal. Estatísticas. Brasília: STF, 2016. Disponível em: http:// portal.stf.jus.br/textos/verTexto.asp?servico=estatistica. Acesso em: 12 jun. 2016.

BRASIL. Supremo Tribunal Federal. Estatísticas. Brasília: STF, 2017. Disponível em: http:// portal.stf.jus.br/textos/verTexto.asp?servico=estatistica. Acesso em: 2 jul. 2017.

CAMBI, Eduardo. Neoconstitucionalismo e neoprocessualismo: Direitos Fundamentais, Políticas Públicas e Protagonismo Judiciário. São Paulo: Almedina, 2016.

CARVALHO, Ernani; LEITÃO, Natália. O novo desenho institucional do Ministério Público e o processo de judicialização da política. Revista Direito GV, São Paulo, n. 2, jul./dez. 2010. Disponível em: http://direitosp.fgv.br/publicacoes/revista/artigo/novo-desenho-institucionalministerio-publico-processo-de-judicializacao. Acesso em: 11 jun. 2016.

GARAPON, Antoine. O juiz e a democracia: o guardião das promessas. Tradução de Maria Luíza de Carvalho. Rio de Janeiro: Revan, 2001.

ISMAIL, Mona Lisa Duarte Abdo Aziz. O papel do Ministério Público no controle de políticas públicas. Boletim Científico ESMPU, Brasília, n. 42-43, p. 179- 208, jan./dez. 2014.

SILVA, Cátia Aida. Justiça em jogo: novas facetas da atuação dos promotores de justiça. São Paulo: Edusp Fapesp, 2001.

TASSINARI, Clarissa. Jurisdição e ativismo judicial: limites da atuação do Judiciário. Porto Alegre: Livraria do Advogado, 2013.

VIANNA, Luiz Werneck; CARVALHO, Maria Alice Rezende de; MELO, Manuel Palacios Cunha; BURGOS, Marcelo Baumann. A judicialização da política e das relações sociais no Brasil. Rio de Janeiro: Revan, 1999.

VILLALOBOS, Marco Feoli. Judicialización de la política y activismo judicial: una 
aproximación a América Latina. Revista Latinoamericana de Derechos Humanos,

Heredia, v. 27, n. 1, p. 75 -98, ene./jun. 2016. Disponível em: http://www.revistas.una.ac.cr/ derechoshumanos. Acesso em: 2 jul. 2017.

YEPES, Rodrigo Uprimny. La judicialización de la política en Colombia: casos, potencialidades y riesgos. Revista Internacional de Derechos Humanos, Mendoza, n. 6, p. 52-69, 2007.

Disponível em: http://www.scielo.br/pdf/sur/v4n6/es_a04v4n6.pdf. Acesso em: 3 jul. 2017.

Como citar: MORAES FILHO, José Filomeno; SÁ, Fabiana Costa Lima de. A contribuição do Ministério Público para a judicialização da política e das relações sociais. Revista do Direito Público, Londrina, v. 15, n. 2, p. 116-134, ago. 2020. DOI: 10.5433/24157-108104-1.2020v15n 2p. 116. ISSN: $1980-511 X$.

Recebido em: 17/04/2019

Aprovado em: 09/08/2019 